\title{
PENGARUH RENDAM KAKI MENGGUNAKAN AIR HANGAT TERHADAP KECEMASAN PADA PASIEN HIPERTENSI
}

\section{Dian Anggri Yanti ${ }^{1 *}$, Tati Murni Karokaro' ${ }^{1}$, Anita Sri Gandaria Purba ${ }^{1}$, Junita Ika Susanti Br. Ginting ${ }^{1}$, Raisha Octavariny ${ }^{2}$, Nurul Fernanda Williani ${ }^{1}$}

${ }^{1}$ Program Studi Keperawatan Program Sarjana, Institut Kesehatan Medistra Lubuk Pakam

${ }^{2}$ Program Studi Kesehatan Masyarakat, Institut Kesehatan Medistra Lubuk Pakam

\author{
JIn. Sudirman No.38 Lubuk Pakam, Kabupaten Deli Serdang, \\ Sumatera Utara - Indonesia \\ *email korespondensi author: diananggriyanti87@gmail.com
}

DOI $10.35451 /$ jpk.v1i1.757

\begin{abstract}
Abstrak
Hipertensi atau dikenal sebagai penyakit darah tinggi adalah suatu keadaan dimana terjadi peningkatan tekanan darah di atas ambang batas normal yaitu 120/80 $\mathrm{mmHg}$ yang mengakibatkan peningkatan angka kesakitan/morbiditas dan angka kematian/mortalitas sehingga dapat menimbulkan kecemasan bagi penderitanya. Kecemasan merupakan respon emosional terhadap penilaian yang subjektif dengan keadaan gelisah, khawatir, takut dan emosi yang meningkat. Rendam kaki menggunakan air hangat salah satu terapi yang memberikan efek terapeutik karena air hangat mempunyai dampak fisiologis pada tubuh untuk mengoksidasi jaringan tubuh dalam mengurangi kecemasan. Tujuan kegiatan untuk mengetahui pengaruh rendam kaki menggunakan air hangat terhadap kecemasan pada pasien hipertensi di Rumah Sakit Grandmed Tahun 2020. Metode yang digunakan dalam kegiatan ini berupa sosialisasi penyuluhan kesehatan terkait pengaruh rendam kaki menggunakan air hangat untuk mengurangi kecemasan pada pasien hipertensi di Rumah Sakit Grandmed Lubuk Pakam sebanyak 42 orang sedangkan instrumen dalam melakukan kegiatan ini menggunakan lembar observasi dan menggunakan alat ukur kecemasan (HARS). Berdasarkan hasil observasi dari sosialiasasi yang dilakukan, membuktikan bahwa ada pengaruh tindakan rendam kaki menggunakan air hangat terhadap penurunan kecemasan pada penderita hipertensi sebelum dan susudah tindakan sosialisasi dilakukan, hal tersebut dibuktikan dengan nilai $p=0,000<0,05$. Kesimpulan; ada pengaruh rendam kaki menggunakan air hangat terhadap kecemasan pada pasien hipertensi.
\end{abstract}

Kata kunci: Hipertensi, Kecemasan, Rendam Kaki Menggunakan Air Hangat

\begin{abstract}
Hypertension or known as high blood pressure is a condition where there is an increase blood pressure above the normal threshold of $120 / 80 \mathrm{mmHg}$ which results in an increase in morbidity/mortality rates and death, which can cause anxiety. Anxiety is an emotional response to a subjective assessment with a state of anxiety, worry, fear and increased emotions. Soak the feet using warm water is one the therapies that provides a therapeutic effect because warm water has a physiological impact on the body to oxidize body tissues in reducing anxiety. Aim; To find out the effect of foot baths using warm water on anxiety in hypertensive patients at the Grandmed Hospital in 2020. Method; in the form of socialization of health education related to the effect of soaking feet using warm water to reduce anxiety in hypertensive patients with a sample of 42 respondents
\end{abstract}


while the instrument uses a questionnaire sheet and observation sheet, using an anxiety measurement tool (HARS). Data analysis used bivariate analysis namely Paired Sample $T$ Test. Results; Bivariate test results with Paired Sample T-Test Test prove that there is an effect of foot bath action using warm water to reduce anxiety before and after the action is carried out proven by the value of $p=0,000<0.05$. Conclusion; there is an effect of soaking the feet using warm water on anxiety in hypertensive patient.

Keywords: Hypertension, Anxiety, Soak Feet Using Warm Water

\section{Pendahuluan}

Hipertensi juga dikenal sebagai tekanan darah tinggi adalah suatu keadaan dimana terjadi peningkatan tekanan darah diatas ambang batas normal yaitu 120/80 $\mathrm{mmHg}$ yang mengakibatkan peningkatan angka kesakitan/morbiditas dan angka kematian/mortalitas (Triyanto, 2016).

Word Health Organization (WHO), batas tekanan darah normal adalah kurang dari 130/85 mmHg. Jika tekanan darah lebih dari 140/90 $\mathrm{mmHg}$ dinyatakan sebagai hipertensi, bagi orang dewasa di atas usia 18 tahun (Rospitaria Almina, 2018). WHO menyebutkan negara ekonomi berkembang memiliki penderita hipertensi sebesar $40 \%$ sedangkan negara maju hanya 35\%, kawasan Afrika memegang posisi puncak penderita hipertensi, yaitu sebesar 40\%. Kawasan Amerika sebesar $35 \%$ dan Asia Tenggara 36\%. Kawasan Asia penyakit ini telah membunuh 1,5 juta orang setiap tahunnya. Hal ini menandakan satu dari tiga orang menderita hipertensi.

Kejadian Hipertensi di Indonesia cukup tinggi, yakni mencapai $32 \%$ dari total jumlah penduduk. Hasil Riset Kesehatan Dasar (Riskesdas) Balitbangkes tahun 2018 menunjukkan prevalensi hipertensi secara nasional mencapai $25,8 \%$. Penderita hipertensi di Indonesia diperkirakan sebesar 15 juta jiwa tetapi hanya $4 \%$ yang hipertensi terkendali. Sebaliknya sebesar $50 \%$ penderita tidak menyadari diri sebagai penderita hipertensi, sehingga mereka cenderung untuk menderita hipertensi yang lebih berat.

Hipertensi juga menimbulkan masalah psikologis, dimana pasien merasa takut dan cemas terhadap penurunan fungsi tubuh akibat penyakit yang menyebabkan ketergantungan fisik kepada orang lain (Padila, 2013). Kecemasan adalah faktor psikologis yang mempengaruhi hipertensi. Banyak orang yang mengalami kecemasan atau stres dapat meningkatkan tekanan darah. Tingkat kecemasan dikelompokkan menjadi 4 yaitu kecemasan ringan, kecemasan sedang, kecemasan berat dan panik (Usman, 2016).

Berdasarkan hal tersebut maka penulis lebih memfokuskan kecemasan pada pasien hipertensi. Untuk mengatasi masalah kecemasan pada penderita hipertensi salah satu terapinya adalah merendam kaki menggunakan air hangat. Dalam presentasi Dinas Kesehatan Indonesia (2014) air hangat membuat kita merasa rileks, menghilangkan rasa sakit dan mengencangkan otot serta melancarkan peredaran darah. Oleh karena itu, terapi merendam kaki dalam air hangat dapat membantu mengurangi stres dan membuat tidur lebih mudah. Penelitian yang dilakukan oleh Akmal (2014) menjelaskan prinsip-prinsip dasar merendam kaki dalam air hangat dapat menyebabkan vasodilatasi pembuluh darah yang juga menyebabkan aliran darah menjadi lancar sehingga otot dapat rileks.

\section{Metode}

Kegiatan Pengabdian Kepada Masyarakat (PKM) ini menggunakan metode berupa sosialisasi penyuluhan kesehatan terkait pengaruh rendam kaki menggunakan air hangat untuk mengurangi kecemasan pada pasien hipertensi. Kegiatan ini dilakukan di Rumah Sakit Grandmed Lubuk Pakam. Sasaran pada kegiatan PKM ini adalah 
pasien hipertensi yang mengalami kecemasan sebanyak 42 orang.

\section{Hasil Dan Pembahasan}

Dari tabel 1 dan 2 ditampilkan data distribusi tingkat kecemasan pasien hipertensi di Rumah Sakit Grandmed Lubuk Pakam sebanyak 42 orang sebelum dan sesudah diberikan penyuluhan tentang rendam kaki menggunakan air hangat.

Tabel 1. Tingkat kecemasan pasien hipertensi sebelum tindakan rendam kaki menggunakan air hangat di Rumah Sakit Grandmed Lubuk Pakam

\begin{tabular}{|c|c|c|c|}
\hline $\begin{array}{l}\mathbf{N} \\
\mathbf{0}\end{array}$ & $\begin{array}{l}\text { Tindakan } \\
\text { Rendam } \\
\text { Kaki } \\
\text { dalam Air } \\
\text { Hangat }\end{array}$ & $f$ & $(\%)$ \\
\hline 1 & $\begin{array}{l}\text { Cemas } \\
\text { Ringan }\end{array}$ & 3 & $7,1 \%$ \\
\hline 2 & $\begin{array}{l}\text { Cemas } \\
\text { Sedang }\end{array}$ & 9 & $\begin{array}{l}21,4 \\
\%\end{array}$ \\
\hline 3 & $\begin{array}{l}\text { Cemas } \\
\text { Berat }\end{array}$ & 10 & $\begin{array}{l}23,8 \\
\%\end{array}$ \\
\hline 4 & $\begin{array}{l}\text { Cemas } \\
\text { Sangat } \\
\text { Berat }\end{array}$ & 20 & $\begin{array}{l}47,6 \\
\%\end{array}$ \\
\hline & Jumlah & 42 & $\begin{array}{l}100 \\
\%\end{array}$ \\
\hline
\end{tabular}

Tabel 2. Tingkat kecemasan pasien hipertensi sesudah tindakan rendam kaki menggunakan air hangat di Rumah Sakit Grandmed Lubuk Pakam

\begin{tabular}{llll}
\hline \multicolumn{3}{c}{ Tindakan f } & $(\mathbf{\%})$ \\
$\mathbf{N}$ & Rendam & \\
$\mathbf{0}$ & Kaki & & \\
& dalam Air & & \\
\multicolumn{3}{c}{ Hangat } & \\
\hline 1 & Tidak 10 & 71,4 \\
& Cemas & & $\%$
\end{tabular}

\begin{tabular}{llll}
2 & $\begin{array}{l}\text { Cemas } \\
\text { Ringan } \\
3\end{array}$ & 11 & $\begin{array}{l}26,2 \\
\%\end{array}$ \\
& $\begin{array}{l}\text { Cemas } \\
\text { Sedang }\end{array}$ & 1 & $2,4 \%$ \\
& & \\
\hline & Jumlah & $\mathbf{4 2}$ & $\begin{array}{l}\mathbf{1 0 0} \\
\%\end{array}$ \\
\hline
\end{tabular}

Tabel 3. Pengaruh Tindakan Rendam Kaki Menggunakan Air Hangat Terhadap Kecemasan Pada Pasien Hipertensi di Rumah Sakit Grandmed Lubuk Pakam Tahun 2020

\begin{tabular}{ccccccc}
\hline Renda & $\mathbf{N}$ & Me & & M & Ma & Nil \\
m & an & St & in & X & ai \\
Kaki & & d. & & & p \\
dalam & & v & & & \\
Air & & t & & & \\
& & & & & &
\end{tabular}

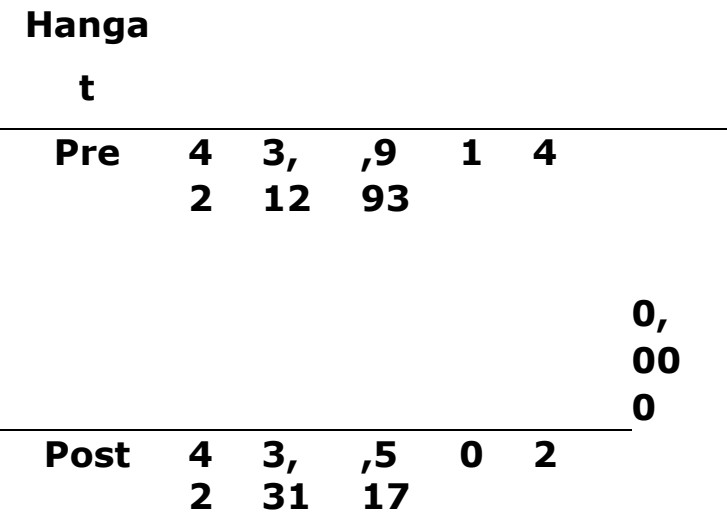

\begin{tabular}{ccc}
\hline Berdasarkan & kegiatan & yang \\
dilakukan, asumsi & pengabdi & yaitu
\end{tabular} didapatkan bahwa Sebelum Tindakan Rendam Kaki Menggunakan Air Hangat kategori Cemas ringan sebanyak 3 orang $(7,1 \%)$, kategori cemas sedang sebanyak 9 orang $(21,4 \%)$, kategori cemas berat sebanyak 10 orang $(23,8 \%)$, dan kategori cemas sangat berat sebanyak 20 orang $(47,6 \%)$. Dan Setelah Dilakukan Tindakan Rendam Kaki Menggunakan Air Hangat kategori tidak cemas sebanyak 30 orang $(71,4 \%)$, kategori cemas ringan sebanyak 11 orang $(26,2 \%)$, dan kategori cemas sedang sebanyak 1 orang $(2,4 \%)$ diruang 
Inap Rumah Sakit Grandmed Lubuk Pakam Tahun 2020.

Hal tersebut didukung oleh hasil penelitian yang dilakukan oleh Damarsanti (2016) yaitu tindakan rendam kaki menggunakan air hangat terhadap kecemasan lansia dengan hasil yang didapatkan nilai tingkat kecemasan normal < 45, kecemasan ringan 46-59 dan kecemasan berat 60-74, kecemasan sangat berat sekali ( panik ) > 75 , variabel bebas dalam kegiatan ini adalah merendam kaki menggunakan air hangat dengan hasil kecemasan sebelum dilakukan tindakan ditemukan nilai kecemasan berat dan sangat berat $98 \%$ dan setelah merendam kaki dengan air hangat nilai kecemasan ringan $96 \%$.

Berdasarkan hasil kegiatan pada tabel 4.3 tentang Pengaruh Rendam Kaki Menggunakan Air Hangat Terhadap Kecemasan Pada Pasien Hipertensi di Rumah, Sakit Grandmed Lubuk Pakam Tahun 2020. Berdasarkan Perubahan Tingkat Kecemasan Pasien Hipertensi di Rumah Sakit Grandmed Lubuk Pakam Tahun 2020, tindakan rendam kaki menggunakan air hangat kategori tidak cemas sebanyak 30 orang $(71,4 \%)$, tindakan rendam kaki menggunakan air hangat kategori cemas ringan sebanyak 11 orang $(26,2 \%)$, dan tindakan rendam kaki menggunakan air hangat kategori cemas sedang sebanyak 1 orang $(2,4 \%)$.

Menurut Penelitian yang dilakukan oleh Sodiqoh (2014) berdasarkan hasil penelitian dapat diketahui bahwa sesudah dilakukan rendam kaki dengan air hangat didapatkan rata-rata tingkat kecemasan adalah 54,13 termasuk tingkat kecemasan ringan ,sedang , standart devisian $\pm 9,674$ nilai tengah 56,60 nilai minimal 41 dan nilai maksimalnya adalah 69. Dengan hasil ada pengaruh rendam kaki dengan air hangat terhadap tingkat kecemasan dengan $p$ value 0,033 dan selisih tingkat kecemasan sebelum dan sesudah sebesar 7,62.

Berdasarkan jumlah skor masingmasing dimensi pada tabel diatas kemudian dilakukan analisa uji statistik dengan metode uji Paired Sample T-Test artinya Ho ditolak sehingga ada Pengaruh Tindakan Rendam Kaki Menggunakan Air Hangat Terhadap Kecemasan Pada Pasien Hipertensi di Rumah Sakit Grandmed Lubuk Pakam Tahun 2020. Interprestasi data yang lebih mudah yaitu dengan melihat indeks $P$ Value sebesar $=, 000<(0,05)$. Oleh karena itu dapat ditarik kesimpulan bahwa Ho di tolak. Sehingga terdapat Pengaruh Rendam Kaki Menggunakan Air Hangat Terhadap Kecemasan Pada Pasien Hipertensi di Rumah Sakit Grandmed Lubuk Pakam Tahun 2020.

Menurut Iwanto (2010) hasil post test didapatkan hasil persentase kecemasan terhadap pasien darah tinggi (hipertensi) yaitu $(2,9 \%)$ responden mengalami kecemasan sedang , $(26,5 \%)$ kecemasan ringan dan $(0,6 \%)$ tidak ada kecemasan. Persentase terbesar yang dialami oleh penderita hipertensi adalah kecemasan sedang. Berdasarkan kegiatan yang dilakukan, asumsi pengabdi yaitu didapatkan bahwa Perubahan tingkat kecemasan pasien hipertensi adalah kategori tidak cemas sebanyak 30 orang $(71,4 \%)$, kategori cemas ringan sebanyak 11 orang $(26,2 \%)$, dan kategori cemas sedang sebanyak 1 orang (2,4\%). Diruang Inap Rumah Sakit Grandmed Lubuk Pakam Tahun 2020. Didukung oleh asumsi penelitian yang dilakukan oleh Heningningsih (2014) Hasil pre-test dan post test didapatkan hasil persentase menggambarkan distribusi hasil dan analisis tingkat kecemasan dengan hasil uji wilcoxon menunjukkan bahwa ratarata tingkat kecemasan pada kelompok perlakuan pada saat pretest berada di tingkat kecemasan sedang dan pada saat posttest berada di tingkat kecemasan ringan, ini menunjukkan bahwa terapi rendam kaki dengan air hangat dapat memberikan pengaruh yang bermakna.

Berdasarkan jumlah skor masingmasing dimensi pada tabel diatas kemudian dilakukan analisa uji statistik dengan metode uji Paired Sample T-Test 
artinya Ho ditolak sehingga ada Pengaruh Tindakan Rendam Kaki Menggunakan Air Hangat Terhadap Kecemasan Pada Pasien Hipertensi di Rumah Sakit Grandmed Lubuk Pakam Tahun 2020. Interprestasi data yang lebih mudah yaitu dengan melihat indeks $P$ Value sebesar $=0,00<(0,05)$. Oleh karena itu dapat ditarik kesimpulan bahwa $\mathrm{Ha}$ diterima Sehingga terdapat Pengaruh Rendam Kaki Menggunakan Air Hangat Terhadap Kecemasan Pada Pasien Hipertensi di Rumah Sakit Grandmed Lubuk Pakam Tahun 2020.

\section{Kesimpulan}

Penurunan tingkat kecemasan pasien hipertensi berdasarkan uji Paired Sample T-Test terdapat perbedaan yang signifikan Antara sebelum dan sesudah dengan hasil nilai sebelum dilakukan tindakan rendam kaki menggunakan air hangat meliputi nilai mean adalah 3,12 ,nilai standar deviation adalah 993, nilai minimum adalah 1 , nilai maximum 4, dan nilai sesudah dilakukan tindakan rendam kaki menggunakan air hangat nilai mean adalah 31, nilai standar deviation adalah 517, nilai minimum adalah 0 , nilai maximum 2. Kemudian disimpulkan bahwa ada pengaruh sebelum dan sesudah merendam kaki menggunakan air hangat untuk mengurangi kecemasan pada pasien hipertensi $(p<0.005)$, sehingga $\mathrm{Ha}$ diterima.

\section{Ucapan Terimakasih}

Ucapan terima kasih kepada Institut Kesehatan MEDISTRA Lubuk Pakam sebagai pendukung secara moril dan materil dalam proses kegiatan pengabdian kepada masyarakat.

\section{Daftar Pustaka}

Annisa, F. D \& Ifdil. (2016). Konsep Kecemasan (Anxiety) pada lanjut usia. Jurnal Konselor Kecemasan pada lansia, Vol. 5, No.2, hal.14129760

Andri \& Adelia, 2019. Pengaruh Rendam Kaki Dengan Air Garam Hangat
Terhadap Tingkat Stres Pada Lansia Wanita Di Puskesmas Dlingo II Kabupaten Bantul Yogyakarta.Jurnal Kesehatan AlIrsyad Vol XII, No.2.

Devsaran. 2014. Rendam Kaki Air Hangat Mempercepatkan Peredaran Darah.

Damayanti, D. (2014). Perbedaan Tekanan Darah Sebelum dan Sesudah Dilakukan Hidroterapi Rendam Hangat Pada Penderita Hipertensi di Desa Kebondalem Kecamatan Jambu Kabupaten Semarang

Hambing, KW. 2016. Keefektifan Rendam Kaki Menggunakan Air Hangat.

Heningsih. (2014). "Gambaran Tingkat Ansietas pada Lansia di Panti Wredha Dharma Bhakti Kasih Surakarta." Skripsi. Surakarta: Program Studi S-1 Keperawatan, Stikes Kusuma Husada Surakarta.

Hawari, Dadang. (2010). Manajemen Stress, Cemas dan Depresi, Jakarta: Fakultas Kedokteran Universitas Indonesia (FKU)

Kusumastuti. 2015. Pengaruh Rendaman Air Hangat Pada Kaki Dalam Meningkatkan Kuantitas Tidur Lansia. Tesis. Jombang: Universitas Pesantren Tinggi Darul Ulum Jombang.

Notoatmodjo, S. 2018. Metodologi Penelitian Kesehatan. Jakarta: Rineka Cipta

Permady, G. G. (2015) Pengaruh Merendam Kaki Dengan Air Hangat Terhadap Kualitas Tidur Lansia Di Wilayah Kerja Puskesmas Astanalanggar Kecamatan Losari Cirebon Jawa Barat. Program Studi Ilmu Keperawatan Fakultas Kedokteran Dan IImu Kesehatan Universitas Islam Negri Syarif Hidayatullah Jakarta.

Rohimah, Siti. 2015. Pengaruh Kompres Hangat Pada Pasien Hipertensi Esensial Di Wilayah Kerja Puskes Kahurpian Kota Tasikmalaya, Jurnal Kesehatan Bakti Tunas Husada Vol.13 
Solechah, N, Masi, G. N. And Rottie, J. V (2017) 'Pengaruh Terapi Rendam Kaki Dengan Air Hangat', Jurnal Keperawatan, 5(1).

Uswandari D. B., (2017), Penelitian Hubungan antara kecemasan dengan kejadian hipertensi pada lansia di Panti Sosial Tresna Werdha.

Uliyah \& Purnaningrum ,Pengaruh Rendam Kaki Dengan Air Hangat Terhadap Tingkat Kecemasan Pada Ibu Hamil, Vol.XI No.2

$\begin{array}{lrr}\text { Wulandari,P., } & \text { Arifianto } & \& \\ \text { Sekarningrum, D. } & (2016) \\ \text { 'Pengaruh } & \text { Rendam } & \text { Kaki } \\ \text { Menggunakan Air Hangat Dengan } \\ \text { Campuran Garam dan Serai } \\ \text { Terhadap Penurunan Tekanan } \\ \text { Darah Pada Penderita Hipertensi } \\ \text { di Wilayah Podorejo RW 8 } \\ \text { Ngaliyan', } \\ \text { 7(2009),pp,43-47. Keperawatan, }\end{array}$

